\title{
Impact of Small Mammals on the Vegetation of Reclaimed Land in the Northern Great Plains
}

\author{
TERRENCE M. HINGTGEN AND WILLIAM R. CLARK
}

\begin{abstract}
This paper analyzes the impact of small-mammal activity on the standing crop of vegetation on areas reclaimed after coal stripmining in northeastern Wyoming. The small-mammal community included 2 carnivorous, 2 herbivorous, and 4 omnivorous species. Deer mice (Peromysucs maniculatus) dominated the population on all areas, constituting $85.4 \%$ of small mammals live-trapped. Plant species preferred as food by deer mice included sainfoin (Onobrychis viciaefolia), fireweed summercypress, (Kochia scoparia), and fourwing saltbush (Atriplex canescens). Grasses had lower preference rankings than forbs. The deer mouse population consumed $20 \mathrm{~g} / \mathrm{ha} /$ day of plant matter. They consumed $0.11 \%$ of the aboveground peak standing crop (PSC) during the growing season, and the consumption of the total small-mammal community was less than $1 \%$ of PSC. However, the PSC of sainfoin was significantly affected by grazing of small-mammal populations.
\end{abstract}

Large tracts of land in the shortgrass prairie of the Northern Great Plains have been strip-mined for coal and require reclamation to levels of productivity that existed before the disturbance. Understanding the role of plant-animal interactions in the reestablishment of vegetation after reclamation is essential to designing successful reclamation procedures for strip-mined land. Small mammals can limit the effectiveness of seedings on rangeland (Nelson et al. 1970), burned brushlands (Howard 1950), and disrupted forest habitat (Radvanyi 1980). Grazing by small mammals specifically has been found to decrease primary production in arctic tundra (Batzli 1975) and desert scrub (Soholt 1973) and the

\footnotetext{
Authors are with the Department of Animal Ecology, Iowa State University, Ames 50011 .

The research was supported by USDA Forest Service, Rocky Mountain Forest and Range Station, Research Work Unit in Rapid City, in cooperation with South Dakota School of Mines and Technology, the AMAX Coal Company, and by the USDI Bureau of Mines, under grant G1106002.

Any opinions, findings, and conclusions or recommendations expressed in this publication do not necessarily reflect the views of the Bureau of Mines, Department of the Interior. We acknowledge D.G. Steward, C. H. Sieg, and D.W. Uresk for reviews of the manuscript.

This is Journal Paper J-10955 of the Iowa Agriculture and Home Economics Experiment Station, Ames, Project 2401.

Manuscript accepted January 9, 1984.
}

volume and cover of vegetation in temperate grassland (Batzli and Pitelka 1970). In simpler ecosystems, greater proportions of total available food are removed by small mammals, up to $10 \%$ in some systems (Petrusewicz and Grodzinski 1975).

The objective of this study was to determine the effect of smallmammal herbivory on the standing crop and species composition of vegetation on land of different ages after reclamation. This paper describes the dietary preferences of deer mice and compares consumption of vegetation during the growing season, estimated from dietary composition, with changes in standing crop of those plant species on plots exclosured from small-mammal populations. Successional changes in small-mammal populations in response to vegetation changes on reclaimed land in the Northern Great Plains are reported elsewhere (Hingtgen 1982).

\section{Methods}

\section{Site Description}

Research was conducted on the Belle Ayr Mine owned by the AMAX Coal Company, located at an elevation of $1,402 \mathrm{~m}, 30 \mathrm{~km}$ south of Gillette, Wyo. Climate in the eastern region of the Powder River basin is semiarid, with an average temperature of $7.4 \mathrm{C}$, average annual precipitation of $360 \mathrm{~mm}$, and a frost-free season from approximately May 21 to September 25 . Rangeland vegetation in the vicinity is dominated by big sagebrush (Artemisia tridentata), needle-and-thread grass (Stipa comata), and blue grama (Bouteloua gracilis).

Reclamation procedures return the overburden to the horizontal strata from which it was removed. After the topsoil has been replaced, seed and fertilizer are drilled into the soil. The basic seed mix consists of wheatgrasses (Agropyron spp.), green needlegrass (Stipa viridula), blue grama, alfalfa (Medicago sativa), yellow sweetclover (Melilotus officinalis), sainfoin, fourwing saltbush, winterfat (Ceratoides lanata), sunflower (Helianthus spp.), basin wildrye (Elymus cinereus), and winter wheat (Triticum aestivum).

Two reclaimed areas were studied in 1980, a 2-year-old area and a 4-year-old area. In 1981, 4 reclaimed areas were studied, a pair of 2-year-old areas, a 3-year-old area, and a 5-year-old area. The 
similarity of vegetation and small-mammal populations on the 3-and 5-year-old areas in 1981 (Hingtgen 1982) led us to treat these similarly throughout our analyses. All reclaimed areas studied are located on north-facing slopes except one 2-year-old area, which is level.

\section{Trapping}

Small mammals were live-trapped monthly on each of the areas from June to August in 1980 and in May, June, August, and September 1981. Species, age (either adult, or juvenile), sex, and reproductive condition of the animals were recorded before they were marked and released (Hingtgen 1982). Population densities were estimated from models for closed populations developed by Otis et al. (1978). To determine food preferences, small mammals were snap-trapped on similarly aged reclaimed areas adjacent to the live-trapping grids.

\section{Vegetation Sampling}

Peak standing crop (PSC) was estimated for each species by harvesting plots exclosed from small mammals by $0.6-\mathrm{cm}$ mesh hardware cloth $1 \mathrm{~m}$ tall, buried $12-15 \mathrm{~cm}$ in the ground, and lined across the top with aluminum flashing. Baited snap-traps placed inside the exclosures for 1 week in late summer indicated that the barrier was rodent-proof. Quadrats within plots were $0.10 \mathrm{~m}^{2}$ in 1980 and $0.25 \mathrm{~m}^{2}$ in 1981 , and were circumscribed by an unharvested $0.25-\mathrm{m}$ strip within the exclosures. Aboveground vegetation was harvested from randomly selected quadrats in each plot at 2-week intervals in July and August 1980 and at monthly intervals from May to August 1981. In June and August 1981, 2 quadrats were harvested in each paired plot to increase the number of samples during peak seasons of growth. Harvested samples were sorted into green and dead standing material, and green vegetation was sorted by species. The standing crop of vegetation at each clipping was estimated from oven-dry weights of green vegetation.

\section{Reference Ranking}

Stomach contents of the animals were reduced to uniform particle size, oven-dried, weighed, and examined under a microscope to determine percentage relative densities of species in the stomach contents. In 1981, oven-dried, stomach samples were sent to the Composition Analysis Laboratory (Department of Range Science, Colorado State University, Fort Collins) for analysis. Values for percentage relative densities of food species were converted to percentage dry weight of the food in the stomach contents (Sparks and Malechek 1968). We treated food items such as seeds and arthropods similarly to plant materials when estimating relative dry weight in the diet and food consumption rates. Analogous structures, such as undigested plant epidermal remnants, seed coats, and chitinous remnants of arthropods, were used to identify food items in the histological analysis. Preferences of deer mice for plant species were determined by comparing mean absolute ranks of dietary occurrence and availability for each food item (Johnson
1980). Standing crop of a species was assumed to reflect availability of that species to the small mammals.

\section{Consumption Rates}

The amount of the PSC consumed by deer mice was estimated from the relative proportion of the food items in the diet, density of consumers, and caloric requirements of the consumers. Energetic costs were estimated by summing energy costs of maintenance and growth and dividing by the coefficient of digestibility (proportion of the ingested food that is digested) for deer mice (Schreiber 1979:148). The caloric content of arthropods, seeds, and green vegetative material is $5.67,5.25$, and $4.88 \mathrm{kcal} / \mathrm{g}$, respectively (Cummins and Wuycheck 1971).

Estimates of consumption by thirteen-lined ground squirrels (Spermophilus tridecemlineatus) were calculated on the basis of minimum energetic costs of existence of $0.233 \mathrm{kcal} / \mathrm{g} / \mathrm{day}$ reported by Scheck and Fleharty (1979), assuming that the diet included 55\% plant material (Flake 1973). Schreiber (1979) estimated consumption of western harvest mice (Reithrodontomys megalotis) in shrub-steppe vegetation, and we assumed similar consumption rates and a dietary composition similar to that observed for deer mice.

In the results that follow, all means are reported plus or minus one standard error. Probabilities given are the exact probabilities of obtaining the test statistics, assuming that the null hypothesis is true.

\section{Results}

\section{Small Mammal Abundance}

The small-mammal community on reclaimed land consisted of 4 omnivorous, 2 herbivorous, and 2 carnivorous species (Hingtgen 1982). Omnivores dominated the population, and deer mice constituted $85.4 \%$ of small mammals captured. All species were captured in greater numbers on older, established reclaimed areas (3-, 4-, and 5-years old) except the western harvest mouse in 1980. Densities of deer mice were similar on 2-year-old and established reclaimed areas averaging $13.0 \pm 1.5$ and $13.9 \pm 1.5 /$ ha, respectively. Naive density estimates (Otis et al. 1978) of western harvest mice on 2-year-old and established reclaimed areas averaged $0.6 \pm 0.4$ and $1.5 \pm 0.4 /$ ha, respectively. Density of thirteen-lined ground squirrels averaged $0.6 \pm 0.3$ / ha on 2 -year-old areas and $1.4 \pm 0.3 /$ ha on established areas. Densities of other species could not be accurately estimated because of the relatively small numbers of captures (Hingtgen 1982).

\section{Food Preferences of Deer Mice}

Plant matter composed an average of $83.2 \%$ dry weight of the stomach contents in $1980(n=62)$ and $45.3 \%$ in $1981(n=68)$. The preference rankings of plant species in the diets of deer mice are shown in Table 1. In general, forbs ranked higher than grasses as preferred food species. Sainfoin was the most consistently highTable 1. Preference ranking of plant species used as food by deer mice on reclaimed land in northeastern Wyoming. Species in the same column with
different numbers have significantly different ranks.

\begin{tabular}{|c|c|c|c|}
\hline \multicolumn{2}{|c|}{$\begin{array}{c}1980 \\
\text { Reclamation Age } \\
\end{array}$} & \multicolumn{2}{|c|}{$\begin{array}{c}1981 \\
\text { Reclamation Age }\end{array}$} \\
\hline 2 Years & 4 Years & 2 Years & 3-5 Years \\
\hline $\begin{array}{l}\text { Yellow sweetclover } 1 \\
\text { Fireweed summercypress } 1 \\
\text { Sainfoin } 1,2 \\
\text { Fourwing saltbush } 2,3,4 \\
\text { Needle-and-thread grass } 3 \\
\text { Alfalfa4 } \\
\text { Common Russianthistle5 } \\
\text { Green needlegrass6 } \\
\text { Wheatgrasses } 7\end{array}$ & $\begin{array}{l}\text { Yellow sweetcloverl } \\
\text { Fourwing saltbush } 2 \\
\text { Sainfoin3 } \\
\text { Alfalfa3 } \\
\text { Needle-and-thread grass } 4 \\
\text { Fireweed summercypress } 4 \\
\text { Common Russianthistle4 } \\
\text { Green needlegrass } 5 \\
\text { Wheatgrasses6 }\end{array}$ & $\begin{array}{l}\text { Fourwing saltbush } 1 \\
\text { Sainfoin } 1,2 \\
\text { Needlegrass-ricegrass 1,2,3 } \\
\text { Mustard2,3,4 } \\
\text { Brome grasses } 3 \\
\text { Common Russianthistle4,5,6 } \\
\text { Wheatgrasses } 5 \\
\text { Fireweed summercypress6 } \\
\text { Alfalfa-sweetclover } 7\end{array}$ & $\begin{array}{l}\text { Sainfoin } 1 \\
\text { Fireweed summercypress } 1 \\
\text { Mustards2 } \\
\text { Common Russianthistle2 } \\
\text { Brome grasses3 } \\
\text { Fourwing saltbush4 } \\
\text { Alfalfa-sweetclover5 } \\
\text { Needlegrass-ricegrass5 } \\
\text { Wheatgrasses6 }\end{array}$ \\
\hline
\end{tabular}


Table 2. Estimated average daily food consumption for the deer mouse population during the growing season in 1981 on reclaimed land in northeastern Wyoming (g/ha/day).

\begin{tabular}{|c|c|c|c|c|c|c|}
\hline \multirow[b]{2}{*}{ Food Type } & \multicolumn{3}{|c|}{2 Years } & \multicolumn{3}{|c|}{ 3-5 Years } \\
\hline & May & June & August & May & June & August \\
\hline Total & $41.8 \pm 3.0$ & $42.1 \pm 3.0$ & $44.3 \pm 3.2$ & $43.2 \pm 3.1$ & $42.1 \pm 3.0$ & $44.8 \pm 3.2$ \\
\hline Arthropods & $33.4 \pm 3.5$ & $26.4 \pm 3.8$ & $18.4 \pm 4.4$ & $26.5 \pm 4.8$ & $26.6 \pm 4.4$ & $11.8 \pm 3.7$ \\
\hline Sainfoin & $0.1 \pm 0.1$ & $0.3 \pm 0.2$ & $14.9 \pm 4.7$ & $13.1 \pm 5.2$ & $4.4 \pm 2.1$ & $13.2 \pm 4.0$ \\
\hline Seeds & $0.9 \pm 0.7$ & $13.5 \pm 3.8$ & $1.2 \pm 1.1$ & $0.4 \pm 0.2$ & $9.2 \pm 3.3$ & $9.7 \pm 3.5$ \\
\hline Fireweed summercypress & $5.4 \pm 2.7$ & $08 \pm 0.3$ & $4.1 \pm 1.6$ & $1.5 \pm 0.6$ & $1.0 \pm 0.6$ & $6.1 \pm 2.9$ \\
\hline Common Russianthistle & $0.8 \pm 0.5$ & $0.4 \pm 0.2$ & $2.8 \pm 2.6$ & $0.0 \pm$ & $0.2 \pm 0.1$ & $0.3 \pm 0.1$ \\
\hline Mustards & $0.0 \pm$ & trace & $1.7 \pm 1.1$ & trace & $0.4 \pm 0.3$ & trace \\
\hline Fourwing saltbush & $0.0 \pm$ & trace & $0.8 \pm 0.6$ & $0.1 \pm 0.1$ & $0.0 \pm$ & $0.2 \pm 0.2$ \\
\hline Alfalfa-sweetclover & trace & $0.6 \pm 0.5$ & $0.0 \pm$ & $0.5 \pm 0.3$ & $0.4 \pm 0.2$ & $0.0 \pm$ \\
\hline Wheatgrasses & $0.0 \pm$ & trace & $0.2 \pm 0.2$ & $0.2 \pm 0.1$ & $0.0 \pm$ & trace \\
\hline
\end{tabular}

ranking food species, and wheatgrasses were most consistently ranked low. Fourwing saltbush and fireweed summercypress were more preferred than common Russianthistle (Salsola kali) and alfalfa, and needlegrasses were most preferred grass species. Mustard species (primarily Camelina microcarpa, Descurainia sophia, and Thlaspiarvense) were not present in harvested plots of vegetation on reclaimed land in 1980 .

Sainfoin was particularly abundant in the diet in August on 2-year-old areas (33.6\% of the estimated average daily food consumption) and in May and August on 3- and 5-year-old areas (30.0\% of daily food consumption, Table 2). It was consumed in significantly greater quantity on 3- and 5-year-old areas than on 2-year-old areas in May $(P=0.022)$ and June $(P=0.058)$. Fireweed summercypress also was relatively abundant in the diet of deer mice, constituting $8.0 \%$ of the estimated total dry weight of food consumed on 2-year-old areas and 7.4\% on 3-and 5-year-old areas.

Arthropods made up $66.8 \pm 4.4 \%$ of the estimated average daily dry weight of food consumed by deer mice during May and June, 1981 (Table 2) and decreased significantly in August on 3- and 5 -year-old reclaimed areas $(P=0.019)$. The decrease in consumption of arthropods was not associated with a decrease in their relative abundance as measured by pitfall and sweepnet samples. Seeds became more important in the diet in midsummer as they became available. Seed consumption increased from May to June on both 2-year-old ( $P=0.005)$ and 3 - and 5-year-old $(P=0.018)$ areas. In August, seed consumption remained relatively high on 3-and 5-year-old areas, compared with significantly less consumption of this food type on 2-year-old areas $(P=0.028)$.

\section{Consumption Rates}

The estimated daily energy requirement for male deer mice, weighing $18.4 \mathrm{~g}$ as adults, was $14.2 \mathrm{kcal} /$ day. Similarly, nongravid adult females weighed $19.0 \mathrm{~g}$ and required $20.4 \mathrm{kcal} /$ day, assuming 1.32 litters produced during the growing season (Schreiber 1979), with 5.3 young/litter (Brown 1966). A weighed average value of $17.3 \mathrm{kcal} /$ day was used to calculate amount of daily consumption for the deer mouse population. Average daily consumption of food by individual decr micc on reclaimed land during the 128-day growing season was $3.23 \pm 0.02 \mathrm{~g} /$ day. Plant material composed an average of $66 \%$ of this daily consumption over the 2 years. Total daily consumption by the deer mouse population (mean consumption per individual $X$ density) was $43.2 \pm 3.1 \mathrm{~g} /$ ha/day of which approximately $20 \mathrm{~g} / \mathrm{ha} /$ day was plant material (Table 2).

The average weight of thirteen-lined ground squirrels captured on reclaimed land was $80 \mathrm{~g}$. Assuming $5.3 \mathrm{kcal} / \mathrm{g}$ average energy content of their food and a digestiblity ratio of 0.88 , similar to that reported by Schreiber (1979) for other rodents, each squirrel would require $4.0 \mathrm{~g} /$ day of food. If the diet is $55 \%$ plant material, 2.2 $\mathrm{g} /$ day of vegetation would be consumed to exactly balance the individual energy requirement. On the basis of our density estimates, the ground squirrel population would consume between 1.3 and $3.1 \mathrm{~g} / \mathrm{ha} /$ day. On the basis of Schreiber's (1979) estimate, individual harvest mice would consume $1.3 \mathrm{~g} /$ day of the plant material. Thus, the harvest mouse population would consume up to $2.0 \mathrm{~g} / \mathrm{ha} /$ day. The total consumption rate of vegetation by the small-mammal community, including all the species of rodents for which we had reasonable estimates, was $25 \mathrm{~g} / \mathrm{ha} /$ day.

\section{Plant Communities and Small-mammal Herbivory}

Dominant plant species on the 3-and 5-year-old areas in 1981 were wheatgrasses, alfalfa, green needlegrass, and fourwing saltbush. In contrast, the dominant species on 2-year-old areas in 1981 were summercypress, alfalfa, common Russianthistle, and mustard species. Total PSC was similar on 2-year-old and 3- and 5-year-old areas in 1981, (Table 3). However, PSC of grasses was

Table 3. Peak standing crop in 1981 on reclaimed land in northeastern Wyoming (g/sq.m).

\begin{tabular}{lcc}
\hline & \multicolumn{2}{c}{ Reclamation Age } \\
\cline { 2 - 3 } Species & 2 Years & $3-5$ Years \\
\hline Total & $229.1 \pm 14.5$ & $238.5 \pm 14.5$ \\
Grasses & $13.5 \pm 5.7$ & $94.9 \pm 5.7$ \\
Forbs and (saltbush) & $215.1 \pm 13.3$ & $142.8 \pm 13.3$ \\
Legumes & $64.8 \pm 9.0$ & $100.6 \pm 9.0$ \\
Alfalfa & $52.2 \pm 8.9$ & $97.2 \pm 8.9$ \\
Yellow sweetclover & $11.4 \pm 2.2$ & $0.0 \pm$ \\
Fourwing saltbush & $0.2 \pm 0.1$ & $8.1 \pm 3.2$ \\
Sainfoin & $1.2 \pm 0.6$ & $1.0 \pm 0.2$ \\
Fireweed summer- & $94.4 \pm 12.4$ & $0.8 \pm 0.9$ \\
$\quad$ cypress & & \\
Needlegrass & $0.4 \pm 0.2$ & $23.0 \pm 2.1$ \\
Common Russianthistle & $33.1 \pm 5.5$ & $3.0 \pm 1.8$ \\
Wheatgrasses & $7.1 \pm 3.5$ & $65.5 \pm 6.6$ \\
Mustard species & $20.2 \pm 3.0$ & $0.4 \pm 0.3$ \\
\hline
\end{tabular}

greater on 3- and 5-year-old areas $(P<0.001)$, whereas PSC of all forbs combined and yellow sweetclover was greater on 2-year-old areas $(P<0.001)$. Total PSC of leguminous forbs, especially alfalfa, was greater on 3- and 5-year-old areas $(P<0.001)$. The PSC of forbs in general was greater on the 3-year-old area (161.4 118.5 $\left.\mathrm{g} / \mathrm{m}^{2}\right)$ than on the 5-year-old area $\left(106.0 \pm 18.5 \mathrm{~g} / \mathrm{m}^{2}, P=0.046\right)$.

The proportion of the total PSC consumed by deer mice, as estimated from average daily food consumption in 1981, was negligible (Table 4). Adding ground squirrels and harvest mice, which were far less abundant than deer mice, still results in total consumption of less than $1 \%$ of PSC. However, deer mice and other rodents consumed a relatively large proportion of the PSC of sainfoin, especially on 3- and 5-year-old reclaimed areas. Larger proportions of the PSC of fireweed summercypress and mustard species were consumed on 3-and 5-year-old reclaimed areas than on 2-year-old areas. On 2-year-old areas, a relatively large proportion of PSC of fourwing saltbush was consumed compared with 
Table 4. Percent of peak standing crop consumed by deer mice during the growing season on reclaimed land in northeastern $W$ yoming.

\begin{tabular}{lcc}
\hline & \multicolumn{2}{c}{ Reclamation Age } \\
\cline { 2 - 3 } Species & 2 Years & $3-5$ Years \\
\hline Total & $0.10 \pm 0.02 \%$ & $0.12 \pm 0.02 \%$ \\
Alfalfa-sweetclover & trace & trace \\
Fourwing saltbush & $2.05 \pm 0.95 \%$ & $0.01 \pm 0.01 \%$ \\
Sainfoin & $6.20 \pm 2.08 \%$ & $13.60 \pm 1.55 \%$ \\
Fireweed summer- & $0.05 \pm 0.01 \%$ & $2.40 \pm 0.96 \%$ \\
$\quad$ cypress & & \\
Common Russianthistle & $0.06 \pm 0.04 \%$ & $0.07 \pm 0.03 \%$ \\
Wheatgrasses & $0.01 \pm 0.01 \%$ & trace \\
Mustard species & $0.04 \pm 0.03 \%$ & $0.47 \pm 0.23 \%$ \\
\hline
\end{tabular}

consumption of other species.

\section{Discussion}

\section{Food Preferences of Deer Mice}

Deer mice are opportunistic omnivores, feeding on the more abundant, efficiently digested available food (Whitaker 1966, Williams 1959). Compared with results of previous studies on undisturbed rangelands (Williams 1959, Johnson 1961, Flake 1973), diets of deer mice on reclaimed land, especially in late summer, consisted of more vegetative material and fewer seeds. A native legume, sainfoin, and an annual forb, fireweed summercypress, were preferred food species in both years. Sainfoin frequently occurred in the diet of deer mice early in the growing season. Everett et al. (1978) have reported a preference by deer mice for seeds of sainfoin, but a preference for green vegetative parts of this species has not been reported. The prevalence of annuals such as fireweed summercypress and common Russianthistle in the diet is consistent with previous food habitat studies of deer mice (Flake 1973, Kritzman 1974). Everett et al. (1978) ranked seeds of alfalfa intermediate in preference and seeds of fourwing saltbush among the least preferred as food for deer mice. Deer mouse consumption of fireweed summercypress, common Russianthistle, mustards, and fourwing saltbush was not a direct response to the amount present and may reflect a need to supplement a "monotonous diet" (Andrzejewska and Gyllenberg 1980).

\section{Energetics}

Estimates of total food consumption derived from the dryweight composition of the diet are higher than those reported by Johnson and Groepper (1970), who found that deer mice required $1.9 \mathrm{~g} /$ day of food averaging $5.57 \mathrm{kcal}$. Schreiber (1979) estimated that deer mice (males $1.2 \mathrm{~g}$, females $16.8 \mathrm{~g}$ ) required $2.9 \mathrm{~g} /$ day of a diet with a mean caloric value of $5.75 \mathrm{kcal} / \mathrm{g}$, averaged over the entire year, but indicated that consumption during the growing season may average only $2.7 \mathrm{~g}$. The consumption estimates for ground squirrels are minimum estimates because they do not reflect the costs of reproduction or that $50 \%$ of the individuals were juveniles with additional requirements for growth.

\section{Impact of Small Mammals on Revegetation}

The pattern of consumption of higher proportions of plant species where they are less abundant indicates the potential of small mammals to alter plant communities. Although the proportion of total PSC consumed is small, the proportion of sainfoin consumed, may affect the establishment of that species. Considering the entire small-mammal community and the scope of their activities, potential exists for small mammals to alter subsequent plant communities. On the basis of estimated consumption by reestablished small mammal populations, the greatest problems for reclamation specialists would be establishing leguminous forbs and shrubs. The established vegetation is the net result of the seeding mixture, prevailing abiotic conditions, and the effects of reinvading herbivores. Given sufficient data on the preferences of herbivores, legumes could be screened for nonpreference (Hewitt et al 1982), alternative foods could be provided (Sullivan and Sullivan 1982), or preferred species could be seeded at higher rates. The most suitable management alternative will depend on the levels of herbivory and the projected uses as grazing land and wildlife habitat.

\section{Literature Cited}

Andrzejewska, L., and G. Gyllenberg. 1980. Small herbivore subsystem. P. 201-267. In: A.l. Breymeyer and G.M. VanDyne, eds. Grasslands, systems analysis and man. Cambridge University Press, New York, N.Y.

Batzli, G.O. 1975. The role of small mammals in arctic ecosystems. P. 243-268. In: F. B. Golley, K. Petrusewiez, and L. Ryskowski, eds. Small mammals: their productivity and population dynamics. Cambridge University Press, London.

Batzli, G.O., and F.A. Pitelka. 1970. Influence of meadow mouse populations on California grassland. Ecology 5I:1027-1039.

Brown, L.N. 1966. Reproduction of Peromyscus maniculatus in the Laramie basin of Wyoming. Amer. Midl. Natur. 76:183-189.

Cummins, K.W., and J.C Wuycheck. 1971. Caloric equivalents for investigations in ecological energetics. Mitt. Int. Ver. Limnol. No. 18.

Everett, R.L., R.O. Meeuwig, and R.Stevens. 1978. Deer mouse preference for seed of commonly planted species, indigenous weed seed, and sacrifice foods. J. Range Manage. 31:70-73.

Flake, L.D. 1973. Food habits of four species of rodents on a shortgrass prairie in Colorado. J. Mammal. 54:636-647.

Hewitt, G.B., A.C. Wilton, and R.J. Lorenz. 1982. The suitability of legumes for rangeland interseeding and as grasshopper food plants. J. Range Manage. 35:653-656.

Hingtgen, T.M. 1982. Small mammals and their impact on reclaimed land in the Northern Great Plains. M.S. Thesis. Iowa State University, Ames.

Howard, W.E. 1950. Wildlife depredation in broadcast seeding of burned brushlands. J. Range Manage. 3:291-298.

Johnson, D.H. 1980. The comparison of usage and availability measurements for evaluating resource preference. Ecology 61:65-71.

Johnson, D.R. 1961. The food habits of rodents on rangelands of southern Idaho. Ecology 42:407-410.

Johnson, D.R., and K.I. Groepper. 1970. Bioenergetics of North Plains rodents. Amer. Midl. Natur. 84:537-548.

Kirtzman, E.B. 1974. Ecological relationships of Peromyscus maniculatus and Perognathus parvus in eastern Washington. J. Mammal. 55:172-188.

Nelson, J.R., A.M. Wilson, and C.J. Goebel. 1970. Factors influencing broadcast seeding in bunchgrass range. J. Range Manage. 23:163-170.

Otis, D.C., K.P. Burnham, G.C. White, and D.R. Anderson. 1978. Statistical inferences from capture data on closed animal populations. Wildl. Monogr. 62.

Petrusewicz, K., and W.L. Grodzinski. 1975. The role of herbivore consumers in various ecosystems. P. 64-70. In: D.E. Reichle, J.F. Franklin, and D.W. Goodall, eds. Productivity of world ecosystems. National Academy of Sciences, Washington, D.C.

Radvanyi, A. 1980. Control of small mammal damage in the Alberta oil sands reclamation and afforestation program. For. Sci. 26:687-702.

Scheck, S.H., and E.D. Fleharty. 1979. Daily energy budgets and patterns of activity of the adult thirteen-lined ground squirrel. Spermophilus tridecemlineatus. Physiol. Zool. 52:390-397.

Schreiber, R.K. 1979. Annual energy budgets for three common rodent species in the northern Great Basin. Great Basin Natur. 39:143-154.

Soholt, L. 1973. Consumption of primary production by a population of kangaroo rats (Dipodomys merriami) in the Mojave desert. Ecol. Monogr. 43:357-376.

Sparks, D.R., and J.C. Malechek. 1968. Estimating percentage dry weight in diets using a microscopic technique. J. Range Manage. 21:264-265.

Sullivan, T.P., and D.S. Sullivan. 1982. The use of alternative foods to reduce lodgepole pine seed predation by small mammals. J. Appl. Ecol. 19:33-45.

Whitaker, J.0. 1966. Food of Mus musculus, Peromyscus maniculatus, and Peromyscus leucopus in Vigo County, Indiana. J. Mammal. 47:473-486.

Williams, O. 1959. Food habits of the deer mouse. J. Mammal. 40:415-419. 